UDC: 811.111'255.4:378.147 https://doi.org/10.22190/JTESAP2003319R

\title{
ESP/LSP/GE FUSION AS AN IMPLEMENTATION OF EDUCATION CONTINUITY IDEAS FROM THE PERSPECTIVE OF FOSTERING VITAL SKILLS OF GENERATION Z IN THE SHADOW OF THE NEW REALITY: CASE STUDY
}

\author{
Svetlana Rubtsova, Tatiana Dobrova \\ Faculty of Modern Languages, St Petersburg State University, Russia \\ E-mail: t.dobrova@spbu.ru
}

\begin{abstract}
Foreign language communication is an essential part of the future professional activities of generation $Z$ students. A professional-oriented approach to teaching a foreign language is therefore becoming particularly relevant. It is common knowledge that the English language varies depending on the content of the professional sphere, with ESP in some spheres sounding as a foreign language to native speakers. Therefore, there is a need to combine ESP, EAP, and GE. The language abilities of generation $Z$ students are changing due to the increase in foreign language content of everyday life. This influences the education environment, which brings modern young people closer to the need of understanding Internet content. It explains the young generation's interest in foreign languages (in $99 \%$ of cases it is the English language). The authors focus on fostering the vital skills of generation $Z$ and provide some recommendations based on the experience gained during the coronavirus pandemic by the Faculty of Modern Languages at St Petersburg University.
\end{abstract}

Key words: generation $Z, E S P, E A P$, university students, distant education

\section{INTRODUCTION}

Nowadays in our globalised world a professional-oriented approach to teaching foreign languages is becoming increasingly relevant. It is undeniable that the English language varies depending on the content of the professional sphere, with ESP in some spheres sounding as a foreign language to native speakers. Therefore, there is a need to combine ESP, EAP, and GE. On top of that, possessing this knowledge does not guarantee success in a world where you need to learn quickly and adapt at 'warp speed', to be flexible, improvise and work a lot in teams (because high-tech products require the coordinated work of different specialists). Information and communication services on the Internet do allow us to organise independent work of students and improve the availability and the quality of education effectively. Blended learning helps to provide the perpetuity of education. The labour market is becoming more and more mobile. In the modern world, one should not expect to be trained for a particular position or workplace. Any type of activity is likely to be automated/digitised, and particular specialists will be made unnecessary.

It is no wonder that transferable skills that make specialists more adaptable to the changing reality have been attracting the attention of both educational institutions and

Submitted October $18^{\text {th }}, 2020$, accepted for publication October $26^{\text {th }}, 2020$ 
employers. The 2030 Agenda for Sustainable Development (Agenda 2015), adopted by all United Nations Member States five years ago, provides 17 Sustainable Development Goals (SDGs). Goal number 4 stands for ensuring inclusive and equitable quality education and promoting lifelong learning opportunities for all. It specifies the necessity "to build and upgrade education facilities that are child, disability and gender sensitive and provide safe, non-violent, inclusive and effective learning environments for all'" The ability to communicate in the professional sphere using foreign languages and IT skills are considered the main transferrable skills (Macmillan 2020).

The compendium of new professions developed by Moscow School of Management SKOLKOVO provides a list of skills that need to be developed for specialists to successfully find their place in the changing picture of the future (Atlas 2014). They are called transferable skills or soft skills.

The main skills are the following:

- Digital literacy;

- Multilingualism and multiculturalism (fluency in English and knowledge of a second foreign language, understanding of the national and cultural context of partner countries, understanding the ins and outs);

- Ability to work with teams, groups, and individuals;

- Working in the atmosphere of high uncertainty and rapid change of task conditions (ability to make decisions quickly, respond to changes in working conditions, ability to allocate resources and manage one's time).

Kjell Nordstrom a Professor at the Swedish school of Economics, speaking at the Synergy Global Forum paid attention to transferable skills as well. He is one of the most famous economists, the author of the book Funky Business - Talent Makes Capital Dance together with his colleague Jonas Ridderstråle (Nordström \& Ridderstråle 2000). The book has become an international best-seller, and has been translated into 33 languages. It is a "manifesto of what our time requires from business firms and their leaders".

Kjell Nordstrom points out that we are only at the very beginning of digitalization. In the future, everything that can be digitized will be digitized. The speed of these changes is incredible. Apple Pay came to Russia just a couple of years ago, but now none of the sales persons at the checkout are surprised that you pay with your phone. The availability of information in the modern world changes the value of higher education. Knowledge in the university world is no longer unique; the monopoly on knowledge no longer exists. You do not need Harvard to gain knowledge from Harvard. If about five years ago being a graduate gave you the green light to any corporation, now all this knowledge is available to anyone. The question now is when will the university diploma die as it is. Kjell Nordstrom believes that this is a matter of several years. Professional knowledge is necessary, but it does not guarantee you success.

When applying for a job, the employers will look not at the professional skills of the applicant, but at the way one lives in the new world: the applicant's usual way of receiving information, the way of communicating in the world network, and what foreign languages and how many of them one speaks. Employers will look for a person with whom they are most comfortable to work, and then provide these candidates with fast and effective professional training. Anyone can become a professional. Not everyone is capable of being efficient. It is the fostering of these transferable skills that the higher school should focus on to adapt to an increasingly changing labour market. In addition, almost any specialist can be trained for a particular job quickly and effectively with the help of specialised courses and training, providing they have some basic competencies. 
To survive in the new conditions, universities should stop being conservative, not try to stop the evolution, but aspire to get the graduates ready to enter the constantly changing labour market. In Russia, we are also aware of the need to provide a greater flexibility in higher education to better match the changing labour market. In January 2020, the President of the Russian Federation V. Putin called for adapting the higher education system to the changing environment. Students should be given the opportunity to choose the direction of training starting from the third year of study, and not from the first one as it is now. The idea is that students are going to be admitted to the university in general, rather than to the law programme or physics programme. Specialisation is to be introduced only after two years of education with only basic disciplines in the curricula. General basic English will be taught as the first foreign language for students of all professional directions for the first two years at the university.

This study is the result of implementing the idea of education continuity in terms of developing foreign language communicative competence in higher education, using the example of the Faculty of Modern Languages at St Petersburg State University in the 'new reality'.

\section{ESP/LSP/GE FUSION IN ST PETERSBURG UNIVERSITY}

English is the first foreign language for all undergraduate programmes at St Petersburg University. Today the discipline «English Language» is a part of the block of basic subjects during the first two years of education. Foreign language competence of students continues to be formed during the $3^{\text {rd }}$ and $4^{\text {th }}$ years. This is at the expense of specialised ESP courses in English, seminars and round tables on the specialty, which are provided mostly by professors of the relevant ESP sphere. The master's programme provides teaching ESP/EAP for two semesters. Then, the foreign language competence of students also continues to be fostered with the help of specialised ESP/EAP courses in English provided by specialists in the relevant sphere of knowledge.

Foreign language communication is now becoming an essential part of the future professional activity of a university graduate. This means that a profession-oriented approach to teaching a foreign language is becoming particularly relevant. The situation is a continuation of the idea that the English language varies depending on the content of the discipline. Therefore, when learning English, it is necessary to connect three models of using English: GE (General English); EAP (English for academic purposes); ESP (English for special purposes). Understanding what the ESP/EAP/GE ratio should be at different stages of English language acquisition has been changing over time. As a rule, we find an approach in which teaching ESP requires a certain level of students' language proficiency. The lowest level, cited in didactic studies, at which ESP training took place is lower beginner (Yogman \& Kaylani 1996).

Taking into account the growing attention to the study of English in secondary school and the forthcoming introduction of mandatory unified state examination in a foreign language in the RF, it is not surprising that most first-year students at the University, who previously studied English, are students with B1 level of English. However, students of international relations, philology, management, global economy and so on demonstrate as a rule level $\mathrm{B} 2, \mathrm{C} 1$, and $\mathrm{C} 2$. We insist on introducing ESP from the very beginning of training for students of all specialisations. The professors of the Faculty of Modern 
Languages have created ESP tests and exercises for 22 specialisations of the University, which provide students with teaching materials different from their school textbooks.

First year students take a placement test at the beginning of September and are distributed into four education paths or 'trajectories'. The percentages of GE/EAP/ESP depending on the education paths we recommend are presented in Table 1.

Table 1 GE/EAP/ESP depending on education paths

\begin{tabular}{|l|l|}
\hline Education path & GE/EAP/ESP \% \\
\hline $\mathrm{A} 1-\mathrm{A} 2$ & $65 / 10 / 25$ \\
\hline $\mathrm{A} 2-\mathrm{B} 1$ & $50 / 15 / 35$ \\
\hline $\mathrm{B} 1-\mathrm{B} 2$ & $25 / 20 / 55$ \\
\hline $\mathrm{B} 2-\mathrm{B} 2+$ & $5 / 25 / 70$ \\
\hline
\end{tabular}

This approach implements the idea of the individualisation of education.

\section{GENERATION Z}

How do we make teaching English at university more effective? For this purpose, we should consider the main characteristics of the generation of students we have to deal with. Generation $\mathrm{Z}$ received its designation in accordance with the theory of generations developed by the American historian and writer William Strauss and the American scientist Neil Howe (Howe \& Strauss 1999). The theory is based on repeating with a certain cyclicity patterns of human behaviour on the scale of history.

Based on the fact that the average life expectancy is 80 years and consists of four periods of approximately 20 years (childhood, youth, middle age, and old age), the authors of the theory define a generation as a set of people who are born every 20 years. For the convenience of description and research, a classification of generations is proposed. The classification is presented in Table 2.

Table 2 The theory of generations

\begin{tabular}{|l|c|}
\hline Generation & Born between \\
\hline Baby Boomers & $1940-1960$ \\
\hline Generation X & $1961-1980$ \\
\hline Generation Y & $1981-1995$ \\
\hline Generation Z & $1996-2017$ \\
\hline
\end{tabular}

The borders between generations are conditional and may differ for different countries, taking into account internal circumstances. For example, in the United States, the Baby Boomer generation is considered to be born after 1939, i.e. after the end of the great depression; in Russia it is 1946, i.e. after the end of World War Two. Nevertheless, general trends within about one generation coincide in different countries, which determined the viability of the generational theory. 
Those born in 1996-1998 have already graduated from universities and colleges and joined the labour market. Those born in 1999-2002 are studying, and many of them work part-time during their 1st or 2nd year at university. Young people born in 2003-2004 are already on the threshold of choosing a life path. Our current students are representatives of Generation Z.

If we talk about fundamental differences, Generation $\mathrm{Z}$ is the first in world history that does not know what a world without computers and the Internet is. What was once the technology of the future for their parents from Generations X and Y, for Generation Z has long been the present and the real world in which they live. Computer technology as the real world in which generation $\mathrm{Z}$ lives is not an exaggeration. According to one of the world's largest commercial banks, Goldman Sachs, young people can spend up to 10 hours a day online.

This is the first truly digital generation. Representatives of Generation $\mathrm{Z}$ actively use tablets, VR-and 3D-reality. Often, the term 'Generation Z' is considered a synonym for the term 'digital person'. Generation $\mathrm{Z}$ is interested in science and technology. They:

- are inextricably linked to gadgets and social networks,

- are involved in digital technologies,

- do not establish strong connections, if they do not like something, they just choose another option - the global network gives a lot of opportunities,

- need to get results quickly,

- prefer more practice while educated.

The boundaries between online and offline for generation $\mathrm{Z}$ are rather arbitrary. Almost everything that happens to them in real life immediately becomes public through social networks and messengers, which young people actively use. It is quite logical that they expect the same from everyone else - openness and willingness to share events. It is desirable that the events are interesting and exciting. This applies not only to friends and the immediate environment - for external communications, young people choose people who also live in networks and give quick feedback. Given that Generation $\mathrm{Z}$ is connected up to 10 hours a day, it is always possible to solve any work issue with them remotely.

The analysis of the main characteristics of generation $\mathrm{Z}$ lets us make the conclusion that there is a need to implement digital technologies. This ensures the efficiency of transferable skills fostered during the process of learning English. The traditional model of education aimed only at obtaining knowledge is hopelessly outdated. It is necessary to transform the educational paradigm itself and review existing approaches and learning models fostering transferable skills. These include digital literacy skills, and social and emotional skills for success in the new digital world.

\section{DigitaliZATION}

The systematic approach to the learning process has changed. Today many subjects are taught with the help of Internet and mobile learning technologies. IT integration into teaching ESP, in particular Internet tools, is one of the most burning nowadays' problem (Beatty 2010, Kakoulli 2018). Independent work of students is performed today, as a rule, through their participation in specially developed activities using electronic resources and Internet communications. 
Teachers of our Faculty have created a database of more than 36,000 tasks in 22 areas of training. These tasks are for four semesters of training and they are uploaded to the Black Board electronic educational system. Each student has the opportunity to master certain grammatical and lexical skills on their own at a convenient time on their mobile phone, according to the recommendation of the teacher. Thus, due to the student-oriented independent tasks, the teacher has the opportunity to choose an individual learning path for each student.

Speaking about the digital approach to education we cannot but mention MOOCs. When teaching ESP/EAP, we encourage our students to use MOOCs. Teachers of the Faculty have created a number of online courses. These include "Preparation for the $\mathrm{PhD}$ English exam" and "English of Law". In addition, we have created six online courses in all lecture subjects of the additional educational programme "Translating in the field of professional communication" which were offered to our students at the beginning of the autumn semester in September 2019. They are: "Theoretical Grammar of the English Language", "Intercultural Communication and Interpreting", "Stylistics of the Russian Language", "Introduction to Translation Theory", "US Studies" and "UK Studies".

\section{METHODS AND AIMS}

Today most of our students and postgraduate students are representatives of generation $\mathrm{Z}$. To meet the needs of the labour market, universities have to provide future specialists with the ability to communicate in their professional spheres using English as lingua franca. The analysis of the main characteristics of representatives of this generation has shown that to make foreign language competence fostering effective it is worth using digital technologies at all stages of teaching English. Elements of ESP and EAP are an integral part of English classes from the very beginning.

The aim of this research is to find out the role of IT in teaching English. To reach the goal the authors conducted the survey with the help of the Google Forms service. We initially planned to find out our students' preferences concerning some vital issues through launching: new online courses at the beginning of the new academic year in September 2019; and an online service for independent students' activities. They included an effectiveness of student-oriented independent tasks uploaded in the Black Board system, and MOOCs while teaching English for postgraduate students and students of the programme "Translating in the field of professional communication". When the pandemic of COVID started we decided to take advantage of the situation and to focus as well on the IT role in teaching English in general taking into account generation $\mathrm{Z}$ peculiarities.

\section{DICUSSION}

In February 2019, we started a pilot project aimed at including tasks uploaded in the Black Board system into the University curricula. The tasks for independent students' activities were divided into blocks, with the number of blocks equal to the number of weeks in the term (15 weeks). Students of 22 areas of professional training had to do the tasks regularly, with continuous assessment at the end of each week. In May 2019 the survey on the effectiveness of student-oriented independent tasks uploaded in the Black 
Board system was conducted. 1568 first- and second-year students took part in the survey. The results are presented in Table 3.

Table 3 Blackboard tasks

\begin{tabular}{|l|c|c|c|}
\hline Question & yes \% & rather yes than no \% & no \% \\
\hline Did you use your smart phone to compete the tasks? & 92 & 7.5 & 0.5 \\
\hline Was it easy to do the tasks? & 57 & 32 & 11 \\
\hline Did you do all the tasks? & 86 & 14 & 0 \\
\hline Did you always do the tasks just before the deadline? & 63 & 9 & 28 \\
\hline Do you find the tasks useful? & 89 & 9 & 2 \\
\hline $\begin{array}{l}\text { Do you prefer independent tasks in the BB system to } \\
\text { classroom activities? }\end{array}$ & 83 & 15 & 2 \\
\hline
\end{tabular}

As the results show, the experiment with the online tasks has proved successful. The vast majority of students believe that independent work in the BB system is useful and saves time. Noteworthy that only $28 \%$ of the respondents did the tasks beforehand, although just $14 \%$ did not do all the tasks. The fact that $92 \%$ of students used their smart phones to do the tasks correlates fully with the result of the analysis of the main features of generation $\mathrm{Z}$ representatives. We would think that it was the fact that the students managed to do online tasks at any convenient time and in any convenient place that made them prefer tasks in the BB system rather than classroom activities.

The second survey was dedicated to the MOOCs created by the faculty professors for postgraduate programmes in the sphere of law and economics, and for the programme "Translating in the field of professional communication". The students of this programme were offered eight MOOCS, i.e. all theoretical disciplines of the programme. We launched the MOOCs in September 2019. At the end of the semester in January 2020, a survey was conducted. 176 students of the programme "Translating in the field of professional communication" and 47 postgraduate students of economics and law took part in it. The results are presented in Table 4.

Table 4 MOOCs or not?

\begin{tabular}{|l|c|c|c|c|c|c|}
\hline Question & \multicolumn{3}{|c|}{176 graduates } & \multicolumn{3}{|c|}{47 postgraduates } \\
\cline { 2 - 7 } & $\begin{array}{c}\text { yes } \\
\%\end{array}$ & $\begin{array}{c}\text { no } \\
\%\end{array}$ & do not know \% & $\begin{array}{c}\text { yes } \\
\%\end{array}$ & $\begin{array}{c}\text { no } \\
\%\end{array}$ & $\begin{array}{c}\text { do not know } \\
\%\end{array}$ \\
\hline Did you find MOOCs useful? & 87 & 11 & 2 & 96 & 3 & 1 \\
\hline $\begin{array}{l}\text { Should all theoretical disciplines } \\
\text { be in the form of MOOCs? }\end{array}$ & 29 & 53 & 18 & 68 & 26 & 6 \\
\hline $\begin{array}{l}\text { Did you get high scores for the } \\
\text { MOOCs tests? }\end{array}$ & 71 & 29 & 0 & 96 & 4 & 0 \\
\hline
\end{tabular}

The survey showed that in general, students rated the experience of using online courses on the programme positively, as $87 \%$ of students and $96 \%$ of postgraduate students responded. While only $29 \%$ of students were willing to completely replace lectures by online courses. They need direct communication with the teachers and with their classmates. This communication makes the classes more effective. The fact that 
most of the postgraduate students (68\%) preferred to do MOOCs may be because most of them worked part time, and it was much more convenient for them. They focus on their careers rather than on interaction with their classmates. We came to the conclusion that blended learning will ensure the most effective learning of subjects.

Due to the threat of Covid-19 proliferation, St Petersburg University had to switch to distance learning. This enabled students to get to know a large number of Internet services, which foreign language teachers began to actively use in every class, not only as their homework, but also as an online class practice.

An online survey was conducted to determine the level of students' awareness of various Internet services that can be used for teaching ESP. These included those aimed at forming a lexical component of the language competence. About 2000 students of St Petersburg University took part in the survey. Students were asked which type of class they preferred regardless of the Covid-19 restrictions (online, offline or blended). The majority of the respondents selected offline $(41.3 \%)$ and blended learning $(35.3 \%)$ as the most appropriate forms of education, specifying that despite convenience of online learning "nothing could be better than real communication". However, an assumption should be made that quite low results for online learning might reflect an overall feeling of fatigue and tiredness caused by the lockdown and students' constant sitting in front of computers and laptops. The results of the survey are presented in Figure 1.

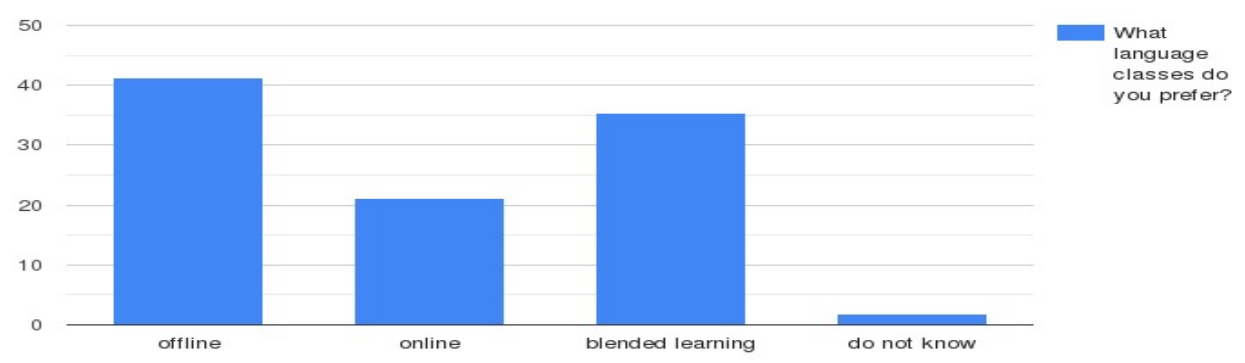

Fig. 1 What language classes do you prefer?

Noteworthy that students and teacher use many online platforms for online classes, with $40 \%$ of students using more than one tool. The results of the survey are presented in Figure 2.

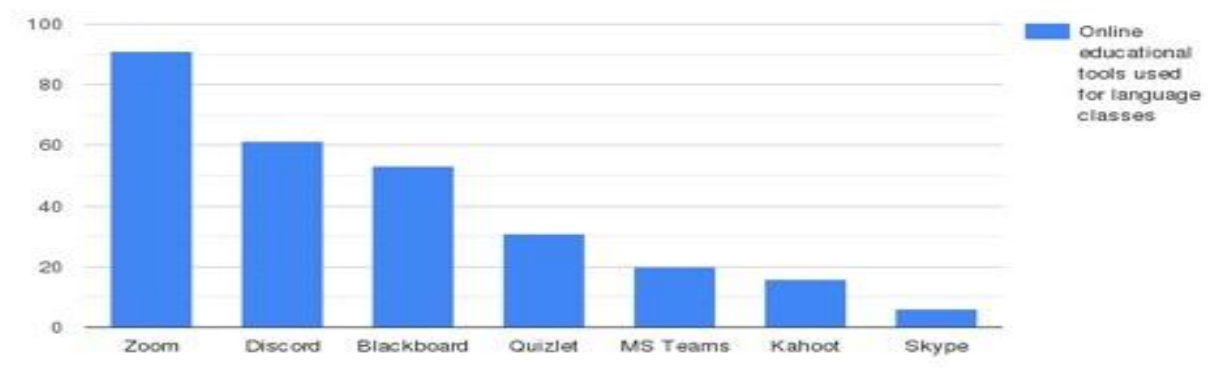

Fig. 2 Online educational tools used for language classes 
The most popular online platform was considered Zoom (91\%), followed by Discord $(61.3 \%)$ and Blackboard $(53.1 \%)$. The others are not so popular: Quizlet $(31 \%)$, MS Teams $(20 \%)$, Kahoot $(16 \%)$ and Skype $(6 \%)$. It is worth mentioning that at the end of 2019 only a few people used Zoom, while Skype was quite popular. Today the situation is absolutely different. We believe that the main reasons are the larger number of participants in Zoom conferences, and more stable operation of the platform when using a smart phone. Finally, two thirds of the students have mentioned that IT-tools would be best used for home tasks. These results are consistent with the answers received on the question what language classes students prefer regardless of the Covid-19 restrictions (online, offline or blended).

Having analysed the results of the survey, we can state that the students believe modern ESP teaching cannot be effective without using online services, both for classroom work and for homework. Although students prefer to use IT tools for homework as they appreciate real communication both with their mates and with teachers. Thus, blended learning seems the best solution.

In June, the Faculty of Modern Languages together with the University School of Translation and Interpreting held an online Summer Translation School. The School was held for three days, more than ten famous interpreters and translators gave presentations and master-classes and over 400 participants listened to them.

It was another opportunity to find out the attitude of our audience to online meetings. The Google form survey was conducted to estimate the results of the event. The comment that seems to be the most typical was:

"I liked the format - as I understand it. Many speakers took part in the Summer School because the online format meant that they did not have to come to St Petersburg. If we had attended in person then probably we would not have been able to hear so many remarkable speakers. Besides recording provided the opportunity to do it at a convenient time."

Answering the question "What is your preferred format for participation in the activities? (regardless of the epidemiological situation)" an equal number of respondents preferred blended participation and online participation, while offline participation was chosen by only $15 \%$ of the respondents (Fig.3).

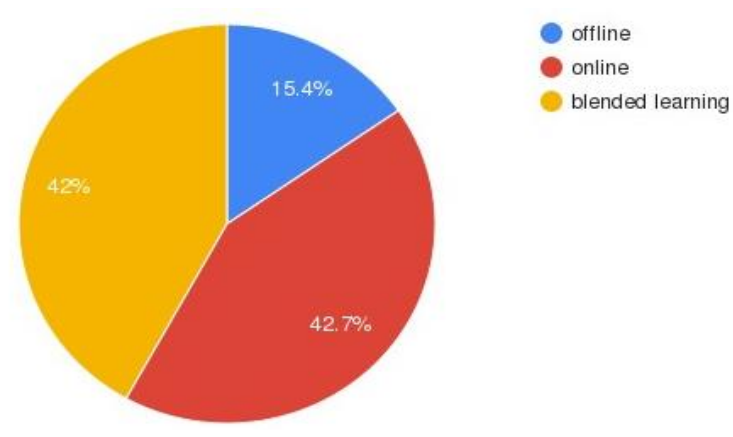

Fig. 3 What is your preferred format for participation in the activities?

Question "How many lectures of the Summer School did you watch online? (there were 12 of them in total)" $25 \%$ preferred to watch later most of the recorded lectures, but still about $70 \%$ watched them online (Fig.4). 


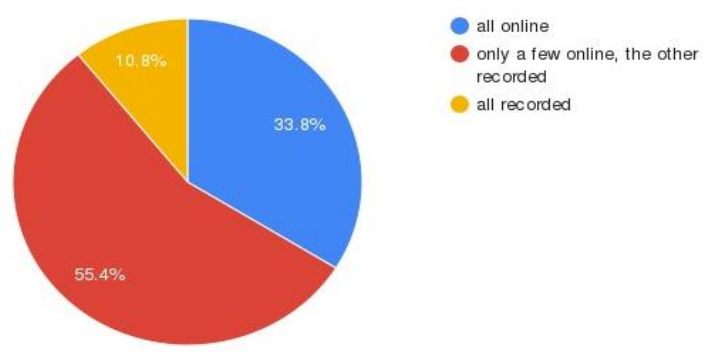

Fig. 4 How many lectures of the Summer School did you watch online?

We asked our participants to estimate the organisers' work. "Please rate the organisational component of the event on a 5-point scale: communication with participants, moderation of discussions, distribution of materials, feedback." And it was highly rated (Fig. 5). We use professional version of Zoom, however there were still some minor technical problems.

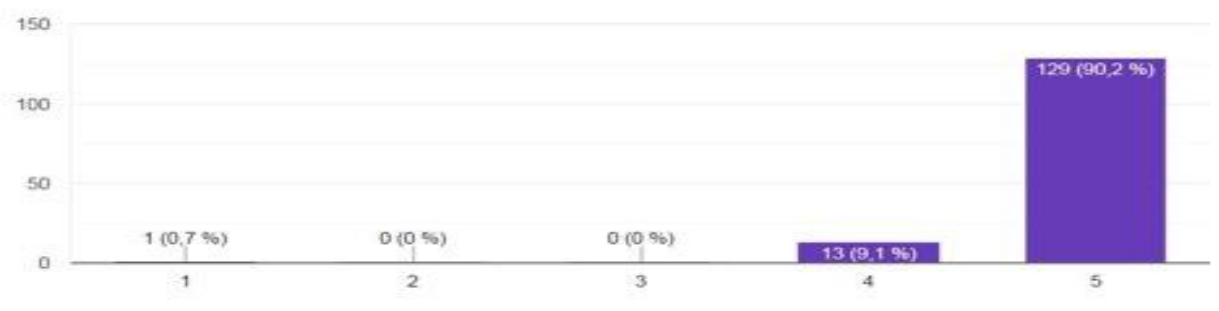

Fig. 5 Please rate the organisational component of the event on a 5-point scale

\section{CONCLUSION}

To sum up we can state that generation Z representatives are "digital natives", they use modern digital technologies easily and constantly in their everyday lives, they appreciate taking online courses or drilling some grammar or lexical difficulties on their smart phones. However, the majority of students are not ready to go completely online in their education. Communication with their mates and teachers is an integral part of the process of education for them, the special psychological atmosphere or "chemistry" during offline classes being hard to overestimate. So, they choose blended learning. While most of postgraduate students prefer MOOCs as they are more independent and concentrated on their carriers rather than communication with their classmates.

The COVID pandemic has forced both teachers and students to use a number of online tools in language education, with Zoom being the most popular.

The experience gained during the Summer Translation School in June 2020 let us conclude that online conferences can become quite popular in the world academic community. However, the majority of the participants preferred to watch lectures online rather than recorded, appreciating the opportunity to take part in the discussion even in chats. 


\section{REFERENCES}

Agenda for Sustainable Development 2015 <https://sustainabledevelopment.un.org/post2015/ transformingourworld/publication> (20 May 2020).

Atlas of new professions (2014). <http://atlas100.ru/about/ > (22 May 2020).

Bates T. Teaching in a Digital Age <https://opentextbc.ca/teachinginadigitalage/chapter/11-1what-do-we-mean-by-quality-when-teaching-in-a-digital-age/> (20 May 2020).

Beatty K. Teaching and Researching: Computer- Assisted Language Learning. Longman, 2010.

ESP program design for mixed level students. JudyYogman, Cora T.Kaylani English for Specific Purposes Volume 15, Issue 4, 1996, Pages 311-324.

Howe, N.; Strauss, W. (1991). Generations: The History of America's Future, 1584 to 2069. https://archive.org/details/generationshisto00stra_0 (25 May 2020).

Kakoulli Constantinou, E. 2018. - Teaching in Clouds: Using the G Suite for Education for the Delivery of Two English for Academic Purposes Courses.l The Journal of Teaching English for Specific and Academic Purposes 6 (2): 305-17. https://doi.org/ 10.22190/ jtesap1802305c. (28 May 2020).

Macmillan. (2020). Little Book of Business Skills. Retrieved from $<$ http://www.businessenglishonline.net/business-2/files/2014/11/Little-Book-of-BusinessSkills.pdf> (25 May 2020).

Nordström, Kjell A.; Ridderstråle, Jonas (2000). Funky business: Talent makes capital dance. $<$ https://books.google.ru/books?id=I8wWzmiz2EsC\&printsec=frontcover\&dq=Kjell+A.+ Nordström\&redir_esc=y\#v=onepage \&q=Kjell\%20A.\%20Nordström\&f=false $>\quad(28$ May 2020). 